\title{
Research on Narrow Context ESP Course Design in Adult Education
}

\author{
Qing $\operatorname{Li}^{1}$ \\ College of Foreign Languages \\ Qingdao Agricultural University \\ Qingdao, China \\ liqingqust@163.com
}

\author{
Xinghua Huo ${ }^{2}$ \\ College of Foreign Languages \\ Qingdao Agricultural University \\ Qingdao, China \\ stormyrose@163.com
}

\begin{abstract}
The degree of social specialization demands the improvement of talents' specialization level, which is manifested in the Adult Higher education. One of the most important aspects is the degree of trainee's English specialization. It is English itself not the language teachers that decided its destiny and has become accountable to the scrutiny of the wider world. The traditional leisurely and purpose-free stroll through the landscape of the English language seemed no longer appropriate in the harsher realities of the social development, which arouse the development of ESP teaching in the adult higher education. How to tackle the fundamental questions in ESP practice and how to design and implement the ESP courses are the most important problems in EFL setting. This research focuses on the principles and practices in ESP course development and the implementation of ESP approach, including pedagogy, to provide the learners professional development with the background of internationalization.
\end{abstract}

Keywords-ESP; English for Specific Purpose; Adult HigherEducation; course design; pedagogy

\section{INTRODUCTION}

Adult higher education has become an important component in adult education of China. However, the number of in-service personnel, job transfer or re-employment workers is small in receiving adult higher education. It showed that the degree of specialization in adult education is not high so that job training or business skills training is not its primary mission. Therefore, the degree of social specialization increases gradually in the current situation, and the general effect of all this development exert pressure on the language teaching profession to deliver the required aims.

However, it is because of the current situation of adult education and background in adult education learners that there are a large proportion of learners in order to obtain a diploma rather than job skills and capability. Thus, teaching objectives, teaching content and teaching methods of the adult continuing education in China are close to the regular higher education which mainly emphasizes theoretical knowledge other than skills training and classroom lectures rather than practical application, ignoring the adult learning characteristics and rules. And these can not reflect the high level of a variety of job training and continuing education after college that features the contemporary adult higher education, especially in English teaching of continuing education.

The inefficiency of English teaching in adult continuing education is due to the complex structure of the learners with various English proficiency and different motivation. The traditional English teaching for general purpose which has emphasized gaining knowledge about language rather than using language for genuinely communicative and vocational purpose results in poor teaching effect. Currently, the social improvement in the level of specialization required a higher level of talent specialization which demands the English courses tailored to specific needs. The new development of education emphasizes the central importance of the learners and their attitudes to learning. Meanwhile, the learners were seen to have different needs and interests, which would have an important influence on their motivation to learn and therefore on the effectiveness of their learning. ${ }^{[1]}$

Thereby, English teaching reform in adult higher education is imperative to fully consider the students' needs and different learning proficiency with the orientation of the employment needs and job-oriented skills training, to change teaching objectives and teaching methods for general purpose, and to increase learners' ability in understanding the professional knowledge in English by providing more flexible learning environment. This also offers support to the development of English courses to their needs and the relevance to their needs would improve the learners' motivation and make the English learning better and efficient.

This research mainly discusses the course design with the guidance of ESP approach in Veterinary Medicine Specialty of adult higher education in Qingdao Agricultural University, combined with the features and current continuing education situation. With the guidance of some successful ESP curriculum design and ESP theory, the ESP course design of Veterinary Medicine Specialty in continuing education is proposed in order to improve the quality of teaching in English. 


\section{ESP THEORY}

\section{A. What is ESP?}

English for Specific Purpose (ESP) is specialized English language teaching that aims to develop specific skills of the learners in response to the needs identified or indicated by various stakeholders. Tom Hutchinson and Alan Waters ${ }^{[2]}$ stated that ESP is an approach to language learning and teaching, which is based on learners' need. Therefore, ESP must be seen as an approach not as a product. ESP is not a matter of teaching 'specialized varieties' of English, and not a matter of science words and grammar for scientists, and ESP is the same as any other form of language teaching in that it should be based on the principles of effective and efficient learning. In short, ESP is not a particular kind of language or methodology, nor does it consist of a special type of teaching material. Swales ${ }^{[3]}$ hold the opinion that the ESP approach is sometimes referred to as Language for Specific Purpose (LSP), because specific-purpose instruction can be in any language. $\mathrm{Orr}^{[4]}$ stated that this 'specialty' includes equipping learners with 'not only knowledge of a specific part of the English language, but also competency in the skills required to use this language'. Thereby, ESP has emerged as an influential pedagogical approach both in EFL and ESL context. ${ }^{[5][6]}$

In the point of view of Tom Hutchinson and Alan Waters $^{[7]}$, the branches of ESP may be divided into two main types of ESP differentiated according to whether the learner requires English for academic study (EAP: English for Academic Purposes) or for work/training (EOP: English for Occupational Purposes). However, this is not so clear-cut distinction because learners can work and study simultaneously or be likely that the language learnt for immediate use in a study environment will be used later when the learner takes up or return to his job. In conclusion, ESP should be properly seen as an approach to language teaching which is directed by specific and apparent reasons for learning.

\section{B. ESP Course Design}

Now that ESP is a matter of approach to language teaching which aims to meet the needs of special group of learners, it means that much work done by ESP teachers is to design appropriate courses for various groups of learners. Even though the course design plays a minor role in general English teaching, it is often a substantial and important part of the workload for ESP teachers. ${ }^{[8]}$

Designing a course is fundamentally a reasoned subsequent process of syllabus design, material design, classroom teaching, and evaluation for general or specific purposes, theoretical or practical purposes. And there are two influential definitions for English for Specific Purposes ${ }^{[9][10]}$ identify 'absolute' and 'variable' characteristics of ESP. The absolute characteristics of ESP courses are listed by Strevens as (1) designed to meet the specified needs of the learner; (2) related in content such as themes and topics to particular disciplines, occupations and activities and (3) centered on language use in those activities [9]. Dudley-Evans and St John ${ }^{[10]}$ listed them as (1) designed to meet the specific needs of the learner; (2) making use of the underlying methodology and activities of the disciplines they sere; and (3) centered on the language (grammar, lexis, register), skills, discourse and genres of activities in those disciplines.

There is a lot of similarity between the two definitions above. They both hold the opinion that ESP courses are devised on the basis of the specific work-related or academic needs of learners and the courses offer descriptions of language use in this disciplines or occupations they serve. ${ }^{[11]}$ There are several factors that affect the ESP course design, which are " $5 \mathrm{~W}+1 \mathrm{H}$ " (What, Who, Why, Where, When and How), as shown in the following Figure. ${ }^{[13]}$

In recent years, there has been a growing tendency toward wide-angled course design in English for Academic Purposes (EAP) ${ }^{[13]}$, while Hyland perceived this tendency negatively and attributes it largely to the reluctance of universities to fund the development of highly specific, that is narrow-angled EAP programs; Ferris ${ }^{[14]}$ reports that in the US the majority of EAP writing classes are based on the generalized skills and process approach. However, Helen Basturkmen ${ }^{[15]}$ argued that there are three different types of ESP course design (as shown in the following Table 1) rather than two as suggested by the narrow-angled \& wide-angled dichotomy.

This paper will talk about the English teaching in adult continuing education in the narrow-angled type from the above point of view of Helen Basturkmen in ESP course design.

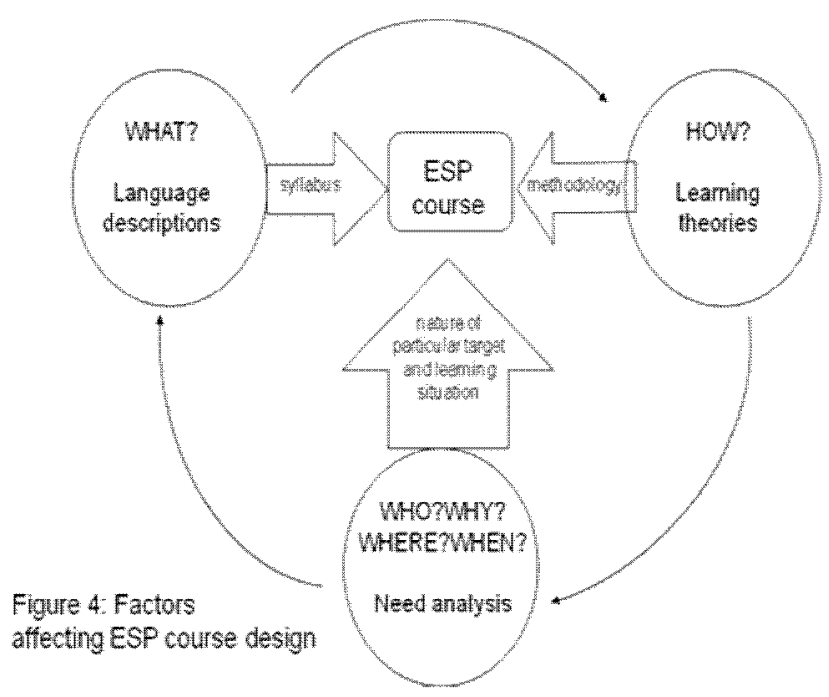


Table 1. Types of course design in ESP

\begin{tabular}{|c|c|l|l|}
\hline Type & $\begin{array}{c}\text { Narro } \\
\text { w } \\
\text { or } \\
\text { Wide } \\
\text { Angle } \\
\text { d }\end{array}$ & $\begin{array}{c}\text { Point of department } \\
\text { for selection of } \\
\text { course content }\end{array}$ & Examples \\
\hline 1 & $\begin{array}{c}\text { Narro } \\
\text { w }\end{array}$ & $\begin{array}{l}\text { Analysis of needs } \\
\text { with reference to a } \\
\text { particular discipline } \\
\text { or occupation }\end{array}$ & $\begin{array}{l}\text { English for pilots } \\
\text { and air traffic } \\
\text { controllers; } \\
\text { English for legal } \\
\text { studies; }\end{array}$ \\
\hline 2 & Wide & $\begin{array}{l}\text { Analysis of common } \\
\text { needs with reference } \\
\text { to a set of disciplines } \\
\text { or occupations }\end{array}$ & $\begin{array}{l}\text { English for } \\
\text { general academic } \\
\text { purposes; }\end{array}$ \\
\hline 3 & Wide & $\begin{array}{l}\text { Features of language } \\
\text { use in a variety of } \\
\text { English }\end{array}$ & $\begin{array}{l}\text { English for } \\
\text { health } \\
\text { professionals; } \\
\text { Business } \\
\text { English; } \\
\text { Academic } \\
\text { English; }\end{array}$ \\
\hline
\end{tabular}

\section{Literature Review on Successful ESP Course Design}

In US, improvement in the means of adult continuing education and degree of social embedding into school system to emphasize the professional development of adult education has become the successful experience in its continuing education system, which provides us important implications. ${ }^{[16]}$ The "degree of social embedding" refers to practical knowledge training and social skill training of adult education learners to satisfy the social needs of personnel market and realize the talent specialization.

In India, English has taken deep roots and spread wide and has become India's language for national and international business, commerce, diplomacy, education, fashion, government, science and technology, etc., which means that English is India's "window on the world" and India's virtual highway to the IT and other markets. Therefore, a number of textbooks that emphasize the use of practical and functional aspects of English are being put into use by influential institutions of higher education. ${ }^{[17]}$

In Japan, the government has called on 8 national conferences on the topic of English teaching and reform in the 21st century. They carried out English Immersion Program in 18 middle schools in order to realize the change from "learning English in middle school" to "learning by English". The Japanese universities have developed its own ESP curriculum design in systemic way. ${ }^{[18]}$

Number of countries have done a range of empirical researches on ESP teaching, which is worthy of domestic concern.
In China, Liu Runqing ${ }^{[19]}$, Cai Jigang ${ }^{[20]}{ }^{[21]}$ pointed out that ESP teaching is the tendency of the 21 st century. With the growing international communication as well as economic globalization, ESP teaching will be the reform direction of college English teaching development in China, especially in adult continuing education. For instance, University of Nottingham, Ningbo and Shanghai Second Military Medical University have gradually carried out the ESP related courses. And more and more people are concerned with the ESP approach and its curriculum design in China.

In summary, ESP teaching is a combination of language teachers and specialty experts' work which is a prerequisite to learning and specific professional goals based on the needs of learners. Combined with the current needs of adult continuing education and the social needs in the application of composite talents, it is determined that the English teaching for nonEnglish majors in adult higher education must develop the combination module of the general English and English for Specific Purposes to stimulate learners' interests and achieve efficient learning.

\section{THE NARROW CONTEXT COURSE DESIGN IN VETERINARY MEDICINE SPECIALTY}

5C (Communication, Cultures, Connections, Comparisons, Communities) principle is American learning standard, among which the "Connections" principle (Communication, Cultures, Connections, Comparisons, Communities) in between disciplines considers that the subjects are consistent with each other. So it is with the module pedagogy. "Module" is a separate unit or blocks, and they both are relatively independent and convergent with other modules. Modules of Employable Skills, that is MES, is a teaching model which was developed in the early 1970s by the International Labor Organization teaching model and mainly used in vocational education. Thereby, this research on narrow context ESP course design will be developed by combining the Modules of Employable Skills with ESP approach to achieve the purpose of the practical use of English in Veterinary Medicine Specialty.

In this narrow context ESP course design, it is divided in to two basic phases which are English basic skills module, that is EGP (English for General Purpose) phase, and vocationoriented ESP course module according to the complicated current situation of learners. The English basic knowledge module in designing is subdivided into 5 aspects as listening, speaking, reading, writing and translation. With the improvement of the learners' English proficiency, the vocation-oriented ESP course module in Veterinary Medicine Specialty is proposed to achieve the ultimate goal of practical communication.

\section{A. The 1st Phase - English Teaching for General Purpose Module Maintaining the Integrity of the Specifications}

With the concern of complicated English proficiency of learners and their needs in English basic knowledge, the English basic knowledge will be taught during the first three semesters but not in the traditional pattern of English teaching for general purpose. In this stage, the theme-related teaching 
method is adopted to combine the five basic skills in English with the content of basic veterinary medicine knowledge. During the classroom teaching, classroom lectures, group discussion, presentation, and role play, etc. will be applied with the full concern of the English five basic skills. The teaching content can be limited in one theme by various means, such as talking about their own poultry farm and introduce kinds of poultry in the farm to their visitors, ask for veterinarian for poultry, why run the poultry farm and their future plan of their farm. This kind of theme-related teaching method integrates their daily life topics with their professional scene rather than professional English, emphasizing their personal involvement, which can provide the content for their conversation. And this kind of training can offer them enough chances to present themselves for their learning with different means and practice their communication competence, and gradually improve their English level, laying the foundation for a professional English teaching module. In the themerelated method, reading can also be taught by group discussion, and then presentation for evaluation.

But the uneven level of English learners must not be ignored, which requires teachers to set tasks from easy to difficult, and expand the differentiated level teaching. It is necessary to make learners have the option in the activities arrangement, task distribution, material selection with flexible teaching methods and content to realize the change from "wants learners to learn" to "learners want to learners" in that the English proficiency of all learners with different levels can be improved.

Meanwhile, the ESP course design requires the centrality of learners' needs and language description. So the modern means of education should be made full use while teaching. The authentic materials can be downloaded for teaching to stimulate learners' interest, for example to realize cultural contrast, community service with the learner-centered approach. Based on the actual needs and respect for individual differences, the teachers should emphasize their experience, learning plan and its implementation and autonomy evaluation. The teachers try to enable them to take full advantage of their limited time during learning and develop a habit of selfdirected learning, which is the difference between adult continuing learning and other kind of regular learning.

\section{B. The 2nd Phase-Vocation-oriented ESP Course Module}

Learners' motivation and attitude to the learning of English need to be taken into consideration in any language planning and course design. So the course design based on the needs of learners is essential, which can stimulate their interests in learning English.

Mortaza Aslrasouli ${ }^{[22]}$ took the idea that the division of courses according to when they take place has three implications. First, this division will affect the degree of specificity that is appropriate to the course ${ }^{[23]}$ After the first phase, the degree of specificity increases, which indicates that in the second phase of this narrow context course design, the specificity should be more focused on the subject-related topics. Second, the timing of the English course can affect the learners' motivation and performance. Research suggested that more specific and subject-related courses have been more successful in motivating learners and really meet their needs. ${ }^{[24]}$ Therefore, in this phase, more specific and subjectrelated course design will be developed for learners, such as class report and presentation. Third, Crofts ${ }^{[25]}$ suggests that EAP materials should concentrate on material that is parallel to the main subject course, but is not actually part of it; topics that could have been included in the main course, but were not. It indicates that material development and how to use it in course design are pretty important.

Combined with both language-centered and skill-centered course design approach, the narrow context ESP course design in Veterinary Medicine Specialty is developed.

With the help of the knowledge and ability acquired in the preliminary module, they have come to the second year of their English learning in their continuing education and have mastered the basic central skills and strategies for applied English and a little bit literature of their specialism. This phase will develop the animal breeding, animal husbandry and veterinary English and so on based on the features of animal science and vocation-oriented needs. First, it involves basic English vocabulary in animal breeding, animal husbandry and veterinary diagnosis, etc.. And then, it comes to the vocationoriented conversation style and genres. The English teaching in this phase starts from reading simple English material in periodical and booklets in animal science, animal husbandry and veterinary medicine. Then it is followed by group discussion and report, retelling activities, and group presentation as one means of evaluation. Gradually, case studies will be applied to veterinary English learning for specific English vocabulary and their native way in expression in order to enhance the learners' English proficiency.

In the application, ESP instructors can design some activities according to the specific needs of learners with the use of "free market needs model", which means that learners provide the specific needs of their professional English in advance, such as simulation of foreign guests visit, consultation in poultry cases, both domestic and international animal breeding conferences and exchanges, so that activities can be targeted to encourage students to complete English boldly under the guidance of teachers with flexible ways and relaxing environment. Only through this way can learners discover and solve problems to achieve pragmatic principle of ESP course design in adult higher education.

At the end of this phase, group PPT presentation will be applied to report the learners' achievements and evaluate their learning. Teachers can organize students to carry out practical language exchange activities, present learning outcomes in group, which is not only to improve their professional communicative competence in English, but also provide learners a way of follow-up self-directed learning to carry out their research or lay the foundation for reading literatures of animal science, offering service for their work.

\section{ESP INSTRUCTIONAL PROCEDURE AND TEACHER}

The ESP instruction is flexible and continually informed by emerging needs of learners and ESP teaching is an approach not a product. As in the course design 
implementation phase, ESP and EGP (English for General Purpose) have a great deal of connections with each other. Concerning the pedagogical choices in language teaching, Brown $^{[26]}$ proposed an "enlightened, eclectic" approach, which entails thinking "in term of a number of possible methodological options at your disposal for tailoring classes to particular contexts."

Hence, to the ESP teachers, they will confront one challenge that is the content area of the learners' specialty or academic discourse ${ }^{[27][28]}$. It is widely agreed that ESP teachers are language educators and cannot be content specialists. So in some cases, dual professionalism can be carried out to train our teacher both in language teaching itself and content area of profession, which is a big difficulty for ESP teachers. However, ESP pedagogy is multidimensional which enables the ESP teachers to be fit for the job with their knowledge of language teaching combined with instructions from the professional teachers or experts in this field or specialty. Furthermore, ESP teachers interact with the human audience in an on-site or off-site context, and thus a lot of social and behavioral variables affect the course dynamics. Consequently, the ESP teachers need to be able to organize and develop the materials according to curriculum. Meanwhile, the ESP teachers also can learn from their learners in the professional knowledge part. In conclusion, the instruction will be considered effective when the learners' satisfaction and needs are met.

This requires the government and university to increase ESP teachers training and better serve the adult higher education. And it can reflect the characteristics of adult education to serve the community and to meet the market demands for contemporary talents.

\section{CONCLUSION}

An ESP program is an ongoing approach which is essentially "purpose-driven and problem-solving"[29] from the beginning to the end. This paper mainly talked about the narrow context ESP course design, taking Veterinary Medicine Specialty as example. A successful ESP program is based on the needs of the learners and the effectiveness of pedagogically sound courses, aiming at fulfilling specific communicative objectives. It reflects both the American Learning Standards (5C Principle) and the ESP theory, focusing on the needs of society and learners, manifesting the subjectivity of learners learning autonomy and actual personal operability in improving the quality of teaching and talent training. Therefore, this is a tentative study in a narrow context ESP course design, which also needs further investigation to improve it in the future when continually implementing it.

\section{ACKNOWLEDGMENT}

Qing Li thanks the financial supporters. This paper is financially supported by the research project in Adult Higher Education of Qingdao Agricultural University, project number: CJ1013; And the research projects "The Exploration and Research on the Reform of College English Teaching of China with the Guidance of American 5C Foreign Language Learning Standards: 613Y49" and "Exploration and Study of
EGP+EGE+ESP Three Dimensional System", project number: XJG1203. And the thanks also goes to the Young Domestic Visiting Scholars Funding Project of Shandong Province.

\section{REFERENCES}

$[1,2,7,8,12]$ T. Hutchinson, \& A. Waters, English for Specific Purposes, Cambridge: Cambridge University Press, (1991), pp. 8,19,16,21,22.

[3] J. Swales, Languages for Specific Purposes. Annual review of Applied Linguistics, (2000), pp. 20, 59-76.

[4] T. Orr, (Ed). English for Specific Purposes. Alexandria, VA: TESOL, (2002), p.1.

[5] H. Basturkmen, Ideas and Options in English for Specific Purposes. Mahwah, NJ: Lawrence Erbaum. (2006).

[6] D. Belcher, A. Johns, B. Paltridge, (Eds.) New Directions in English for Specific Purposes Research. Ann Arbor: University of Michigan Press, (2011).

[9] P. Strevens, ESP after Twenty Years: A Re-appraisal. In M. Tickoo (Ed.), ESP: State of the Art (1-13). Singapore: SEAMEO Regional Language Center, (1988).

$[10,23,27]$ T. Dudley-Evans, M.J. St John, Developments in English for Specific Purposes. A Multi-disciplinary Approach. Cambridge University Press, (1998).

$[11,15]$ H. Basturkmen, Specificity and ESP Course Design. RELC Journal, (2003), 34 (1), pp.48-63.

[13] K. Hyland, 'Specificity Revisited: How Far Should We Go Now?', English for Specific Purposes, (2002), 21, 4, pp.385-395.

[14] D.R. Ferris, 'Teaching Writing for Academic Purposes', J. Flowerdew and M. Peacock (eds.), Research Perspectives on English for Academic Purposes, Cambridge: Cambridge University Press, (2001), pp.298-314.

[16] Zeng Yu. Sino-US Differences in Adult Education: Comparison and Implication, Chinese Adult Education, (2012), 18, pp.20-22.

[17,22,24] Mortaza Aslrasouli, Challenging One-Size-Fits-All Approach in ESP Material Design: Insights from Iran \& India, (2012), pp.1374-1382.

[18] Cai Jigang, Where is the Road for College English Teaching in China, (2013)

[19] Liu Runqing, 21st Century English Teaching - A UK Survey, Foreign Language Teaching and Research, (1996) (2).

[20] Cai Jigang, The Direction of ESP and College English Teaching, Foreign Language World, (2004), 2, pp.22-28.

[21] Cai Jigang, Study on College English Teaching Characteristics and Countermeasures in the Period of Transition in China, Foreign Language Teaching and Research, (2007), 1, pp.27-32.

[25] J.N. Crofts, Subjects and Objects in ESP Teaching Materials. Paper Presented to the Second Regional ESP Conference, Isfahan, Iran, 1979, November, cited in J.M. Swales, (1980), p.67.

[26] S. Brown, Editorial. Active Learning in Higher Education, (2001), p.40

[28] C. Feak, S. Reinhart, An ESP Program for Students of law. In T. Orr (Ed.), English for Specific Purposes. Alexandria, VA: TESOL, (2002), pp.7-24.

[29] D. Belcher, English for Specific Purposes: Teaching to Perceived needs and Imagined Futures in Worlds of Work, Study, and Everyday Life. TESOL Quarterly, (2006), 40, p. 135. 